\title{
Green Supply Chain Management: A New Movement Towards Healthier Environment
}

\author{
${ }^{1}$ Muhammed Kürşad Özlen \\ ${ }^{2}$ Nejra Omerhodžić
}

\begin{abstract}
${ }^{1}$ Ishik University, Business and Management Department, Erbil, Iraq E-mail: kursadozlen@yahoo.com

${ }^{2}$ International Burch University, Bosnia and Gertsogovina
\end{abstract}

\begin{abstract}
The objective of this paper is to establish a picture of to what extent Green Supply Chain Management is present in Bosnia and Herzegovina. Another point of interest in this paper is the measurement of administrative environment, consumer perception and the actual implementation of such a supply chain into daily operations. This study develops a survey questionnaire based on the reviewed literature about Green Supply Chain Management, and conducts the survey on the employees of companies located in one region of Bosnia and Herzegovina and compares the obtained results with the work of others in this field. The findings in this paper are conclusive and indicate a strong tendency towards complete implementation of Green Supply Chain Management into daily operations of Bosnian production companies, an existence of a supportive administrative environment and the strong willingness of people to adapt measures that are acceptable to the environment and create a smaller social cost. Finally, this paper is a testimony of good intent towards the environment supported and executed by those striving to achieve more efficient and less costly, socially acceptable and environmentally healthy solutions for conducting their business.
\end{abstract}

Keywords: Green Supply Chain Management; Survey; Descriptive analyses.

\section{Introduction}

In today's modern world there is a soaring need for making rational and reasonable environmental choices in the evolving field of supply chain management. Considering the literature provided about Green Supply Chain Management (GSCM), it is obvious that a wide framework of reference is not properly deployed. The lack of this reference framework is evident not only for regulatory authorities who are putting in great effort to ease economical growth, but also for the whole economy which is in a struggle to meet new social and ecological standards and to fulfill a moral obligation towards the society and consumers. Not only has the industry put a deeper focus on the increased awareness about the environmental and social impacts resulted by logistics and distribution, but also researchers have been drawn in by this issue. In order to get a better understanding of the "green effects" observed in distribution networks, many studies and researches have emerged over this past decade. It is recognized that transportation of goods and supplies generates not only costs for the industry, but it also creates environmental costs for the society. While the costs for the industry are measurable, the costs for the society and the full impact of these actions are immeasurable and not included in the price consumers pay for a product. These impacts on society are called externalities (Laffont, 2008) and in this case they are negative ones such as congestion, noise, pollution, emission of toxic gases etc. Therefore, for the parties involved, a broader perspective and wider research are necessary in the field of integrated Green Supply Chain Management. Since Green Supply Chain Management has become one of the most interesting fields of research on the topic of Supply Chain Management, the attention of relevant research has found to be focused on Green issue more and more. Hence, there is also a need to see the current picture of Bosnian environment about GSCM consideration. This research therefore aims to descriptively explore the agreement levels of employees of the companies located in one of Bosnian municipalities in order to propose possible implications for research and practice. For this reason, the developed survey questionnaire about GSCM considerations are applied on those companies and analyzed descriptively.

The remaining of the paper is structured as follows: the second part reviews the relevant literature, the third part talks about the methodology. In the fourth section, the results of the analyses are presented. The last two sections discuss and conclude the research. 


\section{Literature review}

According to Ortolani (2008), the "Green impact" approach in Supply Chain Management can be described as the actions whose goal is to measure, evaluate and reduce the negative outcomes and effects of any economic activity projected on the environment. Ortolani (2008) assumes that the rising level of attention on the social and environmental effects that businesses create is consequences of various associated causes such as costumer concern about environmental issues. She also comments on cost indication stating that public perception is a powerful tool especially in sectors such as Corporate Social Responsibility. Stating that environmental issues are becoming part of the business strategy itself, she explains that this is caused by the increasing awareness of costumers about damaging effects and negative social behavior, which in turn affects market perception and stock valuation. In the course of discovery, she identified transparency and effective cost and effect measurements of negative externalities as crucial factors for building trust between producers and costumers, and identifying it as an important tool for better exploiting challenges and opportunities in a Supply Chain. It can be suggested that Innovative companies creates additional value to their Supply Chains by making it more profitable through the adoption of a Green Supply Chain.

Another study by Chan, He and Wang (2011) leads us to believe that the integration of environmentally sound decisions into the Supply Chain, making it thereby "Green", is essential to manufacturers in order to be able to cope with certain environmental standards demanded by the businesses stakeholders. They also point out the importance of the relationship between Supply Chain and marketing. Therefore, it becomes important tool for decision makers in order to reveal the benefits a Green Supply Chain on marketing and profit maximization.

Another research by Chen, Shih, Shyur and Wu (2012) advocate that firms should be aware of external influences and adjust their business techniques to meet external demand and to associate their activities with the trend of "Greenness". The authors believe that "Greenness" will both provide a firm the ability to face new environmental challenges and create a competitive advantage for themselves trough green initiatives.

Hoejmose, Brammer and Millington (2012) in their research state that trust plays a significant role in the relationship between customers and companies. They mainly believe that implementing a Green Supply Chain enhance not only environmental incentives but also profit incentives. Besides they put an accent on the differentiation of firms on business-to-business (B2B) and business-to-customer (B2C) by arguing that a firm in the B2C sector has higher incentives to adapt a Green Supply chain and thus increase the trust built with customers, hence increase their profits and social acceptance.

The increasing role of government involvement in the transition of firms from a standard Supply Chain to a Green Supply Chain is discussed by Arimura, Darnall and Katayama (2011). They describe the importance of implementing the ISO 14001 environmental management standards and managing a Supply chain of the companies which want to have a better control over their environmental and social impacts. The authors provide necessary points to implement this transition by the help of ISO 14001 and steps through a Supply Chain, implementation of ISO 14001 and its final outcomes and benefits for businesses and the environment.

In a study about electronics-based firms in Taiwan, Shang, Lu and Li (2010) investigated the companies' performance and crucial Green Supply Chain Management capability dimensions. They divided the firms into groups and they conclude that the "green marketing" is the most influencing factor for the firms to obtain a competitive edge over the others. Furthermore they explain how implementing a Green Supply Chain develops synergy among partners allowing them to positively influence one another's environmentally sound performance.

Bose and Pal (2012) take in question whether or not it is beneficial to firms to implement environmentally sound decision making in the process of managing a Supply Chain effectively. They try to make a correlation between adopting "green" methods in a Supply chain and identify that firms, large, medium, small, well-known or not known experience a significant response of the market usually after publicly announcing their green actions.

By having gone through an in-depth analysis about Green Supply Chain Management, we can conclusively say that the trend of implementing green initiatives in a business's economic operations has widened its scope over the past few years and that this topic has established itself as one of the major topics in modern Supply Chain Management. Reviewing these researches made it 
quite obvious that the society is demanding a high level of environmental awareness of firms, but also that when implemented the market compensates the companies more trough profit incensement and stock price rise.

\section{Data and Methodology 1Scale Development}

In order to narrow the scope of this paper, the variables and sub-items are extracted from the reviewed literature and further developed into questions, in Appendix, that the survey participants have answered. The variables include (1) The scope of a Green Supply Chain; (2) Reasons for adopting a Green Supply Chain; (3) Main factors enhancing Green Supply Chain Management; (4) Green Supply Chain Management strategies; (5) Internal and external barriers for adopting a Green Supply Chain; and (6) Critical success factors in implementing a Green Supply Chain. Once these variables and sub-items were formulated into questions, the data retrieved was analyzed resulting in the following section formed as a descriptive analysis of the obtained data. The questionnaire consists of six fields each having five questions. In order to measure the agreement levels of the respondents, a 5-point Likert scale is employed (1=strongly disagree, 2=disagree, $3=$ neither, $4=$ agree, $5=$ strongly agree).

\section{Data}

The developed survey has been conducted on the companies located in the territory of the Municipality of Breza, Ze-Do Kanton in Bosnia and Herzegovina. The municipality of Breza is chosen because of the presence of companies operating in production, retail, distribution, recycling and overhaul. Also, as an important factor of choosing this particular area, Breza includes smallsize (2-10 workers) to large-size companies (thousands of workers).

The target population, in this research, includes the employees in all departments from management to production, retail, distribution, logistics, and recycling in order to see the organization-wide perceptions of the employees about "Green" supply chain management. The reason for selecting this particular group is the wish to obtain a realistic view on the perception of actual implementation of "Green" supply chain management.

In the period from November to December 2012 two hundred surveys were passed out and all of them were filled out completely and accurately according to the survey guidelines specified on the survey sheet (see Appendix). The surveys were distributed by hand only and filled out immediately by the participants. While conducting this survey, the companies are observed to be cooperative and the employees are instructed to provide true answers. After conducting the survey, the data was entered into a excel spreadsheet and analyzed descriptively.

\section{Survey results}

\section{Demographics}

In the demographics section of the survey participants had to answer which department they belong, their age and gender. The respondents are observed to be mainly from production and supply (93/200), management (55/200), and sales (40/200). Male respondents (122/200) are responded the questionnaire more than female respondents (78/200). This is not atypical for this kind of industry where the production workers are all male in some firms because of the physical demands of the work. Females are more present in Management and other service related departments. 147 of the respondents are found to be younger than 40 years old.

\section{Questionnaire analysis \\ Supplier Selection}

According to the results obtained from the first group of questions about supplier management in the questionnaire, the respondents seem to be agreeing on the items in this section. They are involved in a green manufacturing process and they qualify their suppliers according to previously determined/ defined selection criteria. They after more rank the suppliers according to the criteria and choose the best among them. They also test the suppliers' products and regularly audit their suppliers (Table 1 ). 
Table 1: Supplier Selection

\begin{tabular}{lcc} 
Items & Mean & Std. Deviation \\
\hline We do an environmental auditing for suppliers & 3.65 & 1.017 \\
$\begin{array}{l}\text { We require a product testing report before } \\
\text { purchasing }\end{array}$ & 4.07 & .908 \\
$\begin{array}{l}\text { We are involved in the green manufacturing process } \\
\text { There is a formal environmental criteria set by our }\end{array}$ & 3.70 & 1.174 \\
$\begin{array}{l}\text { firm for suppliers } \\
\begin{array}{l}\text { We buy only from suppliers that rank highest based } \\
\text { on our criteria }\end{array}\end{array}$ & 4.78 & 1.109 \\
\hline
\end{tabular}

\section{Green Procurement and Logistics}

The companies are identified to have some guidelines prepared for green purchasing and logistics. While transporting their products, they seem to consider not being harmful to the environment. Therefore, they invest to transform their current production and production system in order to reduce the environmentally harmful impacts. They furthermore are detected to be using energy efficient systems (Table 2).

Table 2: Green Production and Supply Chain Logistics

\begin{tabular}{lcc} 
Items & Mean & Std. Deviation \\
\hline $\begin{array}{l}\text { We have green purchasing and logistics guidelines } \\
\text { that take environmental effects into consideration }\end{array}$ & 3.71 & 1.030 \\
$\begin{array}{l}\text { We use energy efficient systems in operating our } \\
\text { production/ warehousing }\end{array}$ & 3.75 & 1.055 \\
$\begin{array}{l}\text { We base the use of transportation on environmental } \\
\text { decisions }\end{array}$ & 3.54 & 1.084 \\
$\begin{array}{l}\text { We invest in transforming our current } \\
\begin{array}{l}\text { transportation and production system to reduce } \\
\text { environmental impacts on society }\end{array}\end{array}$ & 3.62 & 1.124 \\
\begin{tabular}{l} 
We are bound by external purchasing directives \\
\hline
\end{tabular} & 3.82 & 1.018 \\
\hline
\end{tabular}

\section{Company Green Strategy}

The respondents seemed to be slightly informed about ISO 14001 standards about environment and they are implementing the standards. They also seem slightly manage the recycling processes. They are quite agreed that their top management is committed to the environmental considerations. The companies are observed to be giving importance to the health and safety of their employers. Finally, they have designed their internal and external environments according to the green considerations (Table 3).

Table 3: Company Green Strategy

\begin{tabular}{lcc} 
Items & Mean & Std. Deviation \\
\hline $\begin{array}{l}\text { We manage the recycling of our solid waste and are } \\
\text { required by law to do so }\end{array}$ & 3.68 & 1.172 \\
$\begin{array}{l}\text { We are informed about the environmental } \\
\text { management standard ISO14001 and implement it }\end{array}$ & 3.67 & 1.139 \\
$\begin{array}{l}\text { The CEO and management are committed to } \\
\text { environmental improvement }\end{array}$ & 4.03 & .974 \\
$\begin{array}{l}\text { By using environmental practices, our firm protects } \\
\text { the health and safety of our employees }\end{array}$ & 3.87 & 1.058
\end{tabular}


Our organizational internal and external environment are designed according to green considerations

\section{Green Production}

This group of questions is found to be slightly agreed by the respondents. They slightly agree that the products are designed for easier disassembly. They slightly include their suppliers and customers in their new product design. They also seem to moderately recover their products for overhaul and remanufacturing. However, they prevent and remove the harmful results during the manufacturing process. They also seem to be considering the adoption of new techniques in their production to be in line with the environmental policies (Table 4).

Table 4: Green Production

\begin{tabular}{lcc} 
Items & Mean & Std. Deviation \\
\hline $\begin{array}{l}\text { We include suppliers and customers in the design of } \\
\text { new products }\end{array}$ & 3.52 & 1.089 \\
$\begin{array}{l}\text { We adopt new techniques in our production process } \\
\text { to comply with environmental policies }\end{array}$ & 3.64 & 1.139 \\
$\begin{array}{l}\text { We recover products and/ or components from } \\
\begin{array}{l}\text { customers for overhaul and remanufacturing } \\
\text { We design products for easier disassembly }\end{array}\end{array}$ & 3.65 & 1.186 \\
$\begin{array}{l}\text { During manufacturing process the harmful } \\
\text { outcomes are prevented and removed }\end{array}$ & 3.48 & 1.215 \\
\hline
\end{tabular}

\section{Green Competitiveness}

The respondents slightly agree that their operating costs are reduced when they employ green supply chain management (GSCM). They moreover seem to be analyzing the competitors' GSCM understanding and make enhancements where/ when necessary. They seem to be considering the competitors' environment related decisions while improving their choices. They admit that they can catch the new market opportunities by applying GSCM considerations. Finally, they seem to have customer trust compared to their competitors as a result of GSCM applications (Table 5).

Table 5: Green Competitiveness

\begin{tabular}{lcc} 
Items & Mean & Std. Deviation \\
\hline $\begin{array}{l}\text { We take the environmental choices of competitors } \\
\text { into consideration for improving our own }\end{array}$ & 3.76 & 1.020 \\
$\begin{array}{l}\text { We take advantage by analysing GSCM systems of } \\
\text { competitors and improving it where needed }\end{array}$ & 3.67 & 1.062 \\
$\begin{array}{l}\text { We take advantage of new market opportunities by } \\
\text { using GSCM }\end{array}$ & 3.75 & .971 \\
$\begin{array}{l}\text { Implementation of GSCM reduces our operational } \\
\text { costs relative to competitors }\end{array}$ & 3.55 & 1.102 \\
$\begin{array}{l}\text { We enjoy more consumer trust than competitors } \\
\text { because of implementing GSCM }\end{array}$ & 3.78 & 1.062 \\
\hline
\end{tabular}

Product Recycling and End-of-life Cycle

The companies are observed to be slightly considering producing only recyclable products and offering the customers product recycling manuals and opportunities. They are identified to be quite aware all possible recycling options for their firm. They are moreover observed to be assessing the product life cycles during the design stages. Finally, the companies are detected to be very aware of their products' environmental impacts (Table 6). 
Table 6: Product Recycling and End-of-life Cycle

\begin{tabular}{|c|c|c|}
\hline Items & Mean & Std. Deviation \\
\hline $\begin{array}{l}\text { We are aware of all recycling options that are } \\
\text { available for our firm }\end{array}$ & 3.99 & 1.116 \\
\hline We produce only recyclable products & 3.50 & 1.284 \\
\hline $\begin{array}{l}\text { We try to assess the life cycle of our product during } \\
\text { design stages }\end{array}$ & 3.81 & 1.136 \\
\hline $\begin{array}{l}\text { We offer costumers recycling manuals/ guidelines/ } \\
\text { opportunities }\end{array}$ & 3.62 & 1.271 \\
\hline $\begin{array}{l}\text { We are aware of the environmental impacts of our } \\
\text { products }\end{array}$ & 4.19 & 1.003 \\
\hline
\end{tabular}

\section{Discussion}

The findings of this research about the Bosnian companies in a specific region are found to be, slightly or strongly but positively, in line with the derived assumptions from the reviewed literature. The literature states that a rising level of attention on the social and environmental effects that businesses create is a consequence of various associated causes such as costumer concern about environmental issues, which is found to be true since consumers asked in this survey responded that they are interested in a more environmentally aware production process and prefer those products to others. The thesis that environmental issues are becoming part of the business strategy in the literature review is also true for this market because firms are adapting those strategies to gain a competitive advantage over others. According to the results, companies are considering Greenness well while selecting their suppliers, forming their company strategies and evaluating the recycling and life cycles of their products; they seem to be slightly behaving Green while producing and transporting their products and they slightly feel the achieved competitiveness level of their companies as a result of GSCM.

Since the cost indication states that public perception is a powerful tool, the findings of this study assert that Green consideration creates additional value to the firms' Supply Chains by making it more profitable.

The ability to face new environmental challenges while creating a competitive advantage for themselves trough green initiatives is not only recognized by firms in other countries mentioned in the literature review, but also in Bosnia and Herzegovina. The surveyed companies mainly believe that implementing Green Supply Chain has not only environmental incentives but also profit incentives that has been proven to be true in our survey. Also, they put an accent on the differentiation of firms which was recognized by participants of this study.

Even though B\&H is an emerging country with lots of inconsistencies and overlooking in policy making, an increasing role of government involvement as stated in the literature overview is detected to be present and the importance of implementing the ISO 14001 is acknowledged by the findings of the study.

\section{Conclusion}

As stated at the beginning, this research aims to explore the current scenario about GSCM, very hot and top topic in SCM, in Bosnian environment and therefore to be able to derive some implications for relevant research and practice. The conducted survey is the descriptive picture of the state of companies located in the boundaries of Municipality of Breza. As a result of conducting this survey, it has become obvious that the current situation of "green" techniques is not ideal in companies located in this municipality, but that there are strong movements towards implementation of new "green" techniques and enhancements of existing ones.

This survey indicates that there will be a significant change, which is in progress right now, and that more and more companies are approaching toward "green" supply chain management and are in the process of adopting and executing of environmental standards, ISO 14001, energy optimizing technologies and adapting competitive strategies all based on the new "green" movement. 
This research is successful based on many relevant factors. It proves that there is a social awareness and that firms are forced by the preferences of their consumers and stakeholders to act on sound environmental decisions. It also shows that the administrative framework is present and functioning in an acceptable extent. The companies are familiar with the environmental standards such as ISO 14001 and they are enforced to employ those standards by the government and demanded by stakeholders.

There were no obstacles met by this research. All information was transparent and accessible at any given point in time to the full extent without hesitation or limitations. The firms were cooperative and participants as truthful as possible. However, the generalization of the results may not be possible for all Bosnian market, because of possible specific characteristics of the companies in that region. Since the companies are governed by the canton management and for different reasons, the same study may reveal different pictures.

The government could benefit from this study because it is evident that firms, on their own, accept environmentally sound choices to operate their business. This information could be useful for decision makers to adapt even more policies in order to protect the environment. This voluntary act of firms makes it easier to monitor the compliance with the law, and to learn new opportunities for improvement by cooperating with firms and their stakeholders to create new standards for environmental preservation.

This voluntary act of adapting environmental standards indicate enough of how firms profit trough adapting a Green Supply Chain, not only materially but also by building a trust with stakeholders that differentiates their product and hence provides them with a stable market to place the product in.

Public perception is a useful managerial tool, and in this case managers can benefit from this study by simply recognizing the need to change their company structure to a new one that buyers demand and that they prefer. Managers can see that it is evident that consumers want to know that the product they bought was harmless to the environment. By providing consumer satisfaction, the profits will inevitably increase and a long lasting relationship of trust and appreciation will be developed between the firm and their consumers.

This research can give others a good insight of the picture of the companies located in a small municipality, to produce with no external cost, to consider the adaptation of new perspectives and to consider their stakeholders in making new socially beneficial choices. Further researches may employ/ extend the developed survey questionnaire in some further point in time, on some other companies located in a different region, with similar/different industries as a benchmark in determining the success or failure of policies and execution of those in other municipalities.

Finally, Green Supply Chain Management is a movement dictated by consumers and who wants to remain competitive and differentiate their product while building a trustworthy relationship with their consumers will strive to adapt these strategies in their production and daily operations. Because the implementation of environmentally sound decisions bring significant response of the market, by usually driving company stock price up, "Green marketing” has the most impact for firms in order to obtain a competitive edge over others.

\section{References:}

1. Arimura, T.H., Darnall, N. \& Katayama, H. (2011). Is ISO 14001 a gateway to more advanced voluntary action? The case of green supply chain management. Journal of Environmental Economics and Management, 61(2), 170-182

2. Bose, I. \& Pal, R. (2012). Do green supply chain management initiatives impact stock prices of firms?. Decision Support Systems, 52(3), 624-634

3. Chan, R.Y.K., He, H., Chan, H.K. \& Wang, W.Y.C. (2011). Environmental orientation and corporate performance: The mediation mechanism of green supply chain management and moderating effect of competitive intensity. Industrial Marketing Management, 41(4), 557-562

4. Chen, C., Shih, H., Shyur, H. \& Wu, K. (2012). A business strategy selection of green supply chain management via an analytic network process. Computers \& Mathematics with Applications, 64(8), 2544-2557

5. Hoejmose, S., Brammer, S. \& Millington, A. (2012). "Green" supply chain management: The role of trust and top management in B2B and B2C markets. Industrial Marketing Management, 41(4), 609-620 
6. Laffont, J.J. (2008). Externalities. The New Palgrave Dictionary of Economics. doi:10.1057/9780230226203.0537.

7. Ortolani, C. (2008). Parametric Modelling of Freight Networks: Operational and Environmental Costs. Retrieved from http://paduaresearch.cab.unipd.it/3309/1/TesiChiara Ortolani.pdf

8. Shang, K., Lu, C. \& Li, S. (2010). A taxonomy of green supply chain management capability among electronics-related manufacturing firms in Taiwan. J ournal of Environmental Management, 91(5), 1218-1226

9. Zhu, Q., Sarkis, J. \& Lai, K. (2007). Green supply chain management: pressures, practices and performance within the Chinese automobile industry. Journal of Cleaner Production, 15(11- 12), 1041-1052

10. Zhu, Q., Sarkis, J . \& Lai, K. (2007). Initiatives and outcomes of green supply chain management implementation by Chinese manufacturers. Transportation Research Part E: Logistics and Transportation Review, 47(6), 808-821

11. Zhu, Q., Sarkis, J. \& Lai, K. (2008). Confirmation of a measurement model for green supply chain management practices implementation. International Journal of Production Economics, 111(2), 261-273

12. Zhu, Q., Sarkis, J . \& Lai, K. (2010). An organizational theoretic review of green supply chain management literature. International J ournal of Production Economics, 130(1), 1-15

\section{Appendix}

\section{Supply Chain Management Survey Questionnaire}

\section{Please answer all questions}

For each numeric question, circle the number that best reflects your opinion of the factor judged

1 =strongly disagree, 2 =disagree, $3=$ =neither, $4=$ =agree, $5=$ =strongly agree

Circle only one number for each scale

\begin{tabular}{|c|lll|}
\hline \multicolumn{1}{|l|}{ Demographics } \\
\hline a & Your department/unit: \\
\hline b & Your current position/role in dept/unit: \\
\hline c & How long have you been in current position/role?: \\
\hline d & Your highest education level: Doctorate $\quad$ Master $\quad$ Undergraduate Other \\
\hline e & Gender: $\quad$ Male $\quad$ Female & & \\
\hline f & Age: $\quad \leq 30 \quad 31-40 \quad 41-50 \quad 51-60 \quad \geq 61$ \\
\hline
\end{tabular}

\begin{tabular}{|c|c|c|c|c|c|c|}
\hline \multicolumn{2}{|r|}{ 1.Supplier management } & \multicolumn{3}{|c|}{ Disagree } & \multicolumn{2}{|c|}{ Agree } \\
\hline $\mathbf{a}$ & We do an environmental auditing for suppliers & 1 & 2 & 3 & 4 & 5 \\
\hline b & We require a product testing report before purchasing & 1 & 2 & 3 & 4 & 5 \\
\hline c & We are involved in the green manufacturing process & 1 & 2 & 3 & 4 & 5 \\
\hline d & There is a formal environmental criteria set by our firm for suppliers & 1 & 2 & 3 & 4 & 5 \\
\hline e & We buy only from suppliers that rank highest based on our criteria & 1 & 2 & 3 & 4 & 5 \\
\hline
\end{tabular}

\begin{tabular}{|c|c|c|c|}
\hline \multicolumn{2}{|c|}{ 2.Green procurement and logistics } & Disagree & Agree \\
\hline $\mathbf{a}$ & $\begin{array}{l}\text { We have green purchasing and logistics guidelines that take environmental effects } \\
\text { into consideration }\end{array}$ & 12 & 4 \\
\hline $\mathbf{b}$ & We use energy efficient systems in operating our production/warehousing & 1 & 4 \\
\hline C & We base the use of transportation on environmental decisions & 1 & 4 \\
\hline $\mathbf{d}$ & $\begin{array}{l}\text { We invest in transforming our current transportation and production system to } \\
\text { reduce environmental impacts on society }\end{array}$ & 12 & 4 \\
\hline e & We are bound by external purchasing directives & 12 & 4 \\
\hline
\end{tabular}




\begin{tabular}{|c|c|c|}
\hline \multicolumn{2}{|r|}{ 3.Internal environmental management practices } & Disagree Agree \\
\hline a & We manage the recycling of our solid waste and are required by law to do so & $\begin{array}{lllll}1 & 2 & 3 & 4 & 5\end{array}$ \\
\hline b & $\begin{array}{l}\text { We are informed about the environmental management standard ISO14001 and } \\
\text { implement it }\end{array}$ & 12 \\
\hline C & The CEO and management are committed to environmental improvement & 12 \\
\hline $\mathbf{d}$ & $\begin{array}{l}\text { By using environmental practices our firm protects the health and safety of our } \\
\text { employees }\end{array}$ & 1 \\
\hline $\mathbf{e}$ & $\begin{array}{l}\text { Our organizational internal and external environment are designed according to } \\
\text { green considerations }\end{array}$ & 12 \\
\hline
\end{tabular}

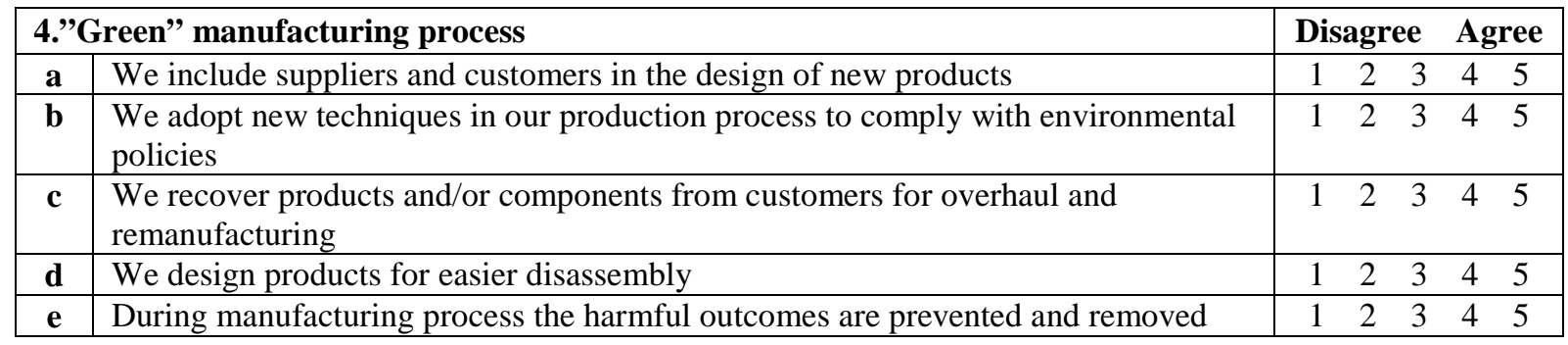

\begin{tabular}{|c|c|c|c|c|c|c|}
\hline \multicolumn{2}{|c|}{ 5.Competitiveness } & \multicolumn{5}{|c|}{ Disagree } \\
\hline $\mathbf{a}$ & $\begin{array}{l}\text { We take the environmental choices of competitors into consideration for improving } \\
\text { our own }\end{array}$ & 1 & 2 & & & \\
\hline b & $\begin{array}{l}\text { We take advantage by analysing GSCM systems of competitors and improving it } \\
\text { where needed }\end{array}$ & & 2 & & & 5 \\
\hline C & We take advantage of new market opportunities by using GSCM & 1 & 2 & 3 & 4 & 5 \\
\hline d & Implementation of GSCM reduces our operational costs relative to competitors & 1 & 2 & 3 & 4 & 5 \\
\hline $\mathbf{e}$ & We enjoy more consumer trust than competitors because of implementing GSCM & 1 & 2 & 3 & 4 & 5 \\
\hline
\end{tabular}

\begin{tabular}{|c|c|c|c|c|c|}
\hline \multicolumn{2}{|r|}{ 6.Product recycling and end-of-life cycle } & \multicolumn{4}{|c|}{ Disagree Agree } \\
\hline $\mathbf{a}$ & We are aware of all recycling options that are available for our firm & 1 & 2 & 3 & 45 \\
\hline b & We produce only recyclable products & 1 & 2 & 3 & 4 \\
\hline C & We try to assess the life cycle of our product during design stages & 1 & 2 & 3 & 4 \\
\hline d & We offer costumers recycling manuals/guidelines/opportunities & 1 & 2 & 3 & 4 \\
\hline e & We are aware of the environmental impacts of our products & 1 & 2 & 3 & 4 \\
\hline
\end{tabular}

Part II: Please add here any positive /negative comments regarding the issue

\title{
Экологические аспекты управления цепями поставок: новый шаг к здоровой экологии
}

\author{
${ }^{1}$ Мухаммед Куксад Озлен \\ ${ }^{2}$ Нейра Омерходзич
}

${ }^{1}$ Ишик университет, бизнес и менеджмент департамента, Эрбиль, Ирак

E-mail: kursadozlen@yahoo.com

2 Международный университет Барч, Босния и Герцоговина

Аннотация. Цель данной работы - представить до какой степени экологические аспекты управления цепями поставок актуальны для Боснии и Герциговине. Еще одна задача - измерить административную среду, представление потребителей и реальное внедрение такой сети в ежедневную работу. В данном исследовании, на основе рассмотренной литературы о экологических аспектах управления цепями поставок, разработан опросник и проведен опрос среди служащих компаний, расположенных в одном регионе Боснии и Герциговины. Проведен сравнительный анализ полученных результатов с 
другими работами в данной сфере. Полученные данные - информативны и отражают тенденцию в пользу полного внедрения экологических аспектов управления цепями поставок в ежедневную работу производственных компаний Боснии, существование поддерживающей административной среды и сильного желания людей принять меры, допустимые для окружающей среды и назначить меньшую социальную цену. В конечном итоге, данная статья является свидетельством доброй воли по отношению к окружающей среде, поддерживаемой и выполнимой данным стремлением, целью которой является достижение более эффективных и менее затратных, социально приемлемых и экологически безвредных решений ведения бизнеса.

Ключевые слова: экологические аспекты управления цепями поставок; опрос; описательный анализ. 